\title{
Training untuk Mencapai Nilai TOEFL Ideal di Masa Pandemi bagi Mahasiswa Universitas Bumigora
}

\author{
Syamsurrijal $^{1}$, Titik Ceriyani Miswaty ${ }^{2}$, M. Zaki Pahrul Hadi ${ }^{3}$ \\ rijalhalilintar@gmail.com ${ }^{1}$, titik_ceriyani86@gmail.com², \\ zakipahrul@universitasbumigora.ac.id ${ }^{3}$ \\ 1,2,3 Universitas Bumigora
}

Article History:

Received: 09-02-2021

Revised: 12-07-2021

Accepted: 22-07-2021

Keywords : English Language, TOEFL Test.

\begin{abstract}
This community service aims to provide not only knowledge but also readiness to face the TOEFL exam for Bumigora University students. This community service is carried out at Bumigora University for one month. The target community is the campus community, namely students. The method used in this community service is to provide tips and strategies in answering the TOEFL test to UBG students. The cost of this community service activity is fully sourced from the community service implementation team.After the implementation of community service activities in the form of English language training, students have sufficient ability and readiness to take the actual TOEFL test.
\end{abstract}

\section{Pendahuluan}

Persaingan global dalam berbagai bidang menuntut penguasaan kompetensi skill dan akademik yang memadai dan dapat dipertanggungjawabkan. Dalam dunia pendidikan nasional Indonesia berbagai bentuk upaya telah dilakukan sebagai persiapan untuk menghadapi persaingan global ini, terutama untuk menghasilkan lulusan yang mampu bersaing, baik untuk melanjutkan ke jenjang pendidikan yang lebih tinggi maupun dalam dunia kerja. Selain upaya-upaya yang dilakukan pemerintah Kementerian Pendidikan Nasional, berbagai upaya juga dilakukan secara mandiri oleh berbagai sekolah dasar, menengah maupun pendidikan tinggi, antara lain dengan mencanangkan mutu pendidikan dan pengelolaan bertaraf internasional. Komitmen ini sebenarnya memiliki implikasi dan konsekuensi yang tidak kecil bagi sekolah atau lembaga pendidikan yang bersangkutan.

Banyak hal yang harus dilakukan akibat pencanangan mutu pendidikan dan pengelolaan yang bertaraf internasional. Banyak hal yang dilakukan mulai dari pembenahan fasilitas, perbaikan kurikulum, pengembangan materi ajar, perbaikan sistem pengelolaan administrasi maupun akademik, dan yang paling mendasar juga berupa peningkatan kemampuan sumber daya manusia yang akan menjalankan dan mendukung komitmen 
tersebut.

Seiring dengan berkembangnya zaman, paradigma pendidikan di Indonesia mengalami perubahan. Hal itu sejalan dengan diberlakukannya Undang-Undang Sistem Pendidikan Nasional Nomor 20 Tahun 2003 yang memberikan kewenangan kepada lembaga- lembaga pendidikan usia dini, dasar, menengah, dan pendidikan tinggi untuk mengembangkan kurikulum sesuai dengan kebutuhan sekolah atau yang lebih dikenal dengan desentralisasi pendidikan.

Desentralisasi pendidikan yang dimaksud yaitu pengembangan kurikulum yang dilakukan oleh daerah atau sekolah yang bersangkutan. Pengembangan kurikulum tidak hanya dilakukan pada tingkat SD, SMP, dan SMA melainkan juga di tingkat Perguruan Tinggi. Sebagai contoh dan gambaran, dengan diberlakukannya standar mutu internasional maka sebuah sekolah telah berkomitmen untuk memasuki sebuah ranah pengelolaan yang tidak lagi berpatokan pada standar dan tuntutan mutu lokal sehingga memerlukan sumber daya manusia yang mampu memahami seluk beluk informasi yang dibutuhkan mendukung kinerja dalam mewujudkan komitmen tersebut.

Berdasarkan analisis situasi dapat diidentifikasi permasalahan sebagai berikut :

1. Upaya peningkatan kemampuan berbahasa Inggris mahasiswa Universitas Bumigora, dalam hal ini mahasiswa, terutama dalam hal kemampuan penguasaan bahasa Inggris dirasa belum mencukupi.

2. Universitas Bumigora sangat minim melaksanakan pelatihan Bahasa Inggris dalam bentuk pelatihan TOEFL sebagai salah satu upaya untuk meningkatkan kemampuan penguasaan bahasa Inggris bagi mahasiswa.

Berdasarkan identifikasi permasalahan tersebut, dapat dirumuskan rumusan masalah sebagai berikut:

1. Bagaimana training untuk Mencapai Nilai TOEFL Ideal di Masa Pandemi dapat memotivasi Mahasiswa Universitas Bumigora untuk meningkatkan penguasaan bahasa Inggris mereka?

2. Bagaimana training untuk Mencapai Nilai TOEFL Ideal di Masa Pandemi dapat meningkatkan kemampuan pemahaman bahasa Inggris mahasiswa Universitas Bumigora? 


\section{Metode}

Pengabdian kepada masyarakat ini melalui beberapa tahapan atau langkah-langkah diantaranya:

\section{Sasaran Kegiatan}

Masyarakat sasaran dalam pengabdian kepada masyarakat ini adalah mahasiswa yang berada di Universitas Bumigora Mataram. Pemilihan peserta pelatihan dilakukan secara random kepada seluruh mahasiswa Angkatan Tahun Akademik 2019/2020 yang mana kemudian terdaftar sejumlah 36 (tiga puluh enam) mahasiswa Universitas Bumigora Mataram yang aktif dan berpartisipasi untuk mengikuti Pelatihan TOEFL Terpadu dan Efektif ini.

\section{Waktu dan Tempat}

Pengabdian kepada masyarakat ini dilaksanakan dengan menggunakan dana mandiri tim pengabdian. Pengabdian kepada masyarakat ini berbentuk Pelatihan TOEFL Terpadu dan Efektif yang dilaksanakan selama empat pekan yang disi dengan pertemuan-pertemuan pelatihan melalui daring di Ruang perpustakaan Universitas Bumigora Mataram. Demi kelancaran kegiatan ini komunikasi dan kerjasama dilakukan bersama pihak pengelola perpustakaan Universitas Bumigora Mataram untuk mengatur jadwal kegiatan sehingga disiplin, tertib dan teratur mulai awal hari pelaksanaan dan sampai berakhirnya kegiatan. Alasan dipilihnya kegiatan pengabdian kepada masyarakat dipusatkan di lokasi perpustakaan ini adalah karena sarana dan prasarananya mendukung untuk pelakasanaan pelatihan sekaligus mendukung dalam teknis pelaksanaan ujian tes TOEFL.

\section{Metode Kegiatan}

Pengabdian kepada masyarakat yang diselenggarakan ini dengan bentuk pelatihan kepada mahasiswa universitas Bumigora Mataram tentang pelatihan TOEFL selama empat pekan dengan jadual empat kali pertemuan pada setiap pekannya.

Pengabdian kepada masyarakat ini dikarenakan berbentuk pelatihan, maka diawali dengan acara pembukaan yang dibuka secara daring di perpustakaan Universitas Bumigora Mataram bersama pengelola perpustakaan dan unsur lainnya. Selanjutnya metode yang digunakan dalam pelatihan meliputi :

a. Metode pre-test kepada seluruh peserta pelatihan dengan maksud mengetahui kemampuan awal peserta sebelum diberikannya materi pelatihan;

b. Metode penyampaian materi pelatihan tentang Structure yaitu mengenai Tata Bahasa (Grammar) Bahasa Inggris yang disampaikan oleh Dr. Titik Ceriyani Miswati, M.Pd 
yang mana materi structure meliputi Part of Speech, dantenses.

c. Metode penyampaian materi pelatihan tentang Listening yang disampaikan oleh $\mathrm{M}$. Zaki Pahrul Hadi, M.Pd. Listening disini bertujuan untuk memberikan kemampuan dalam mendengarkan percakapan Bahasa Inggris.

d. Metode penyampaian materi pelatihan tentang Reading yang disampaikan oleh $\mathrm{Dr}$. Syamsurrijal, M.Hum untuk mengajak mahasiswa memahami isi bacaan teks Bahasa Inggris.

e. Metode post-test kepada seluruh peserta pelatihan dengan maksud mengetahui kemampuan awal peserta setelah diberikannya materi pelatihan dengan test TOEFL.

\section{Pembahasan}

Upaya peningkatan kualitas sumber daya manusia di dunia pendidikan yang berkaitan dengan penguasaan bahasa asing terutama bahasa Inggris, merupakan suatu hal yang sangat penting. Hal ini didasari atas berbagai pertimbangan. Sesuai dengan era yang memberlakukan standar mutu internasional, sebuah lembaga pendidikan tinggi telah berkomitmen untuk memasuki sebuah ranah pengelolaan yang tidak lagi berpatokan pada standar dan tuntutan mutu lokal sehingga memerlukan sumber daya manusia yang mampu memahami seluk beluk informasi yang yang dibutuhkan dalam segala ranah sehingga dapat mendukung kinerja mereka dalam mewujudkan komitmen lembaga.

Upaya mendukung kesiapan sumberdaya sebagai tenaga yang handal di dunia kerja maupun untuk melanjutkan studi ke jenjang yang lebih tinggi maka diperlukan upaya yang kongkrit dan serius dimulai inovasi pembelajaran dan pelatihan - pelatihan yang bertujuan untuk meningkatkan pengetahuan dan kemampuan mahasiswa dan dosen atau tenaga pendidik dituntut menyampaikan materi dalam proses pembelajaran dengan berbagai hal yang kreatif dan inovatif termasuk penyampaian - penyampaian materi secara dwi-bahasa yang ke depan merupakan tuntutan wajib bagi sekolah- sekolah bertaraf internasional. Hal ini tentu saja mustahil dilaksanakan jika para mahasiswa maupun dosen tidak memiliki kompetensi berbahasa Inggris. Oleh karena itu, upaya untuk meningkatkan penguasaan bahasa Inggris bagi mahasiswa dan dosen merupakan bukti keseriusan sebuah institusi untuk mewujudkan komitmen menuju sekolah bertaraf internasional.

Proses pelaksanaan dan hasil kegiatan pengabdian kepada masyarakat ini mendapatkan sambutan positif dari pihak civitas akademika Universitas Bumigora terutama sambutan dari pihak mahasiswa karena program ini sesuai dengan kebutuhan mereka. 
Bentuk sambutan positif tersebut antara lain terlihat dari partisipasi dan keaktifan mahasiswa yang sangat baik dari peserta selama pelatihan. Motivasi peserta untuk mengikuti proses pelatihan ini sangat antusias. Hal ini menandakan adanya keinginan untuk meningkatkan kemampuan mereka dalam penguasaan Bahasa Inggris dan pemahaman pentingnya menguasai Bahasa Inggris, terutama dalam bidang pendidikan dewasa ini termasuk dalam segala hal bidang yang lain. Antusiasme ini juga tercermin dari peningkatan skor yang didapat oleh peserta pelatihan setelah mengikuti pelatihan ini.

Setelah kegiatan selesai dilaksanakan diharapkan pihak universitas melakukan upayaupaya tindak lanjut untuk meningkatkan kemampuan penguasaan Bahasa Inggris tidak hanya kepada mahasiswa saja tetapi juga untuk dosen nantinya. Hasil yang didapat selama pelatihan diharapkan mampu menjadi pemacu semangat bagi pihak universitas maupun peserta pelatihan untuk selalu meningkatkan kemampuan mereka dalam bidang Bahasa Inggris sehingga tujuan-tujuan universitas untuk peningkatan kualitas sumberdaya manusianya dapat segera tercapai.

Terlepas dari harapan di atas, pihak tim pengabdian kepada masyarakat berharap relasi kedua pihak dapat tetap terjalin karena bagaimanapun kegiatan yang berhubungan dengan Bahasa Inggris di instansi manapun juga merupakan concern dari institusi pendidikan dimana tim pengabdian kepada masyarakat bernaung.

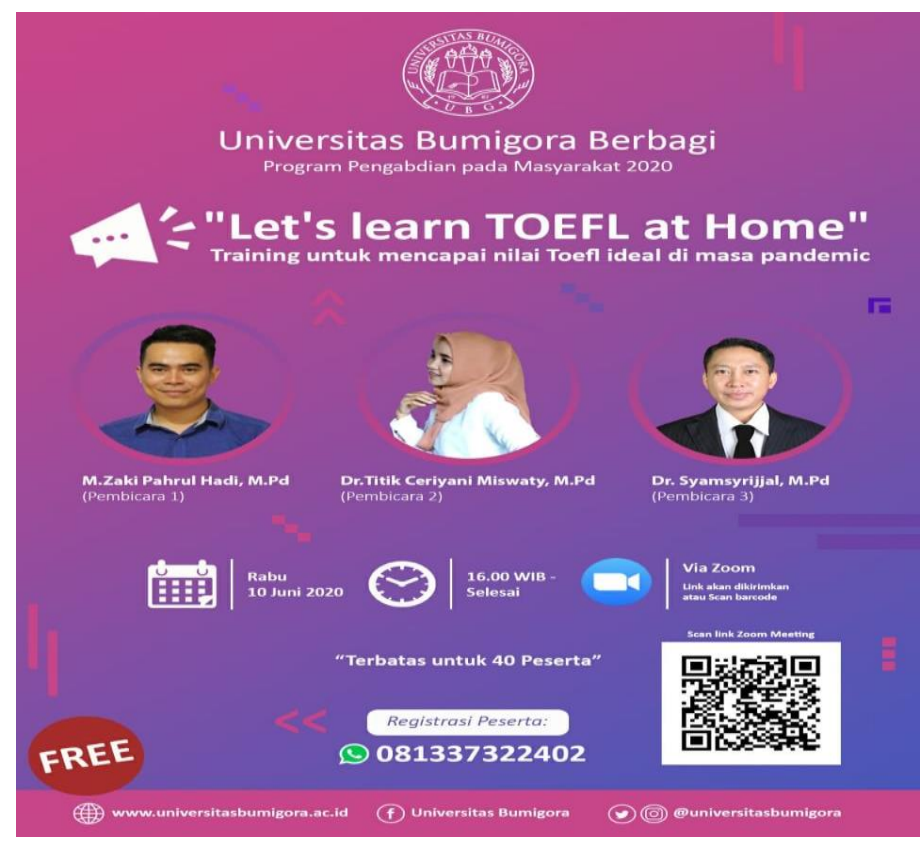

Gambar 1. Flyer kegiatan

Program Pengabdian Masyarakat ini khalayak sasarannya adalah mahasiswa Universitas Bumigora jurusan sastra Inggris dan jurusan lain. Jumlah mitra ini ditetapkan 
ADMA

Gurnal Pengabdian dan Pemberdayaan Masyarakat
Tahun 2021, Vol.2, No.1, pp.85-92

Doi: $10.30812 / a d m a . v 2 i 1.1197$

dengan mempertimbangkan efisiensi dan intensitas pelaksanaan program. Mitra yang dimaksud adalah mahasiswa dan mahasiswi Universitas Bumigora. Jenis permasalahan yang ditangani dalam program PKM meliputi pemberian pengetahuan berupa tips dan strategi dalam meningkatkan nilai TOEFL dan pelatihan tes TOEFL. Aspek yang dilatih dan pengabdian ini adalah Listening comprehension, Structure atau grammar dan reading comprehension.

Pada hakekatnya, kegiatan PKM ini memberikan solusi terhadap permasalahan yang dihadapi mitra melalui pendekatan secara terpadu, agar dapat meningkatkan pengetahuan dan kemampuan dalam bahasa Inggris. Adapun perubahan pasca PKM yang diharapkan adalah sebagai berikut:

Tabel 1. Perubahan pasca PKM yang diharapkan

\begin{tabular}{c|c|c|c}
\hline No. & Unsur & Pra PKM & Pasca PKM \\
\hline 1 & $\begin{array}{c}\text { Kemampuan dalam } \\
\text { Listening comprehension }\end{array}$ & $\begin{array}{c}\text { Belum memiliki } \\
\text { keterampilan }\end{array}$ & $\begin{array}{c}\text { Memiliki kemampuan } \\
\text { berupa kemampuan } \\
\text { menangkap point - point } \\
\text { dan percakapan bahasa } \\
\text { Inggris }\end{array}$ \\
\hline 2 & $\begin{array}{c}\text { Kemampuan dalam } \\
\text { structure atau grammar }\end{array}$ & $\begin{array}{c}\text { Belum memiliki } \\
\text { keterampilan }\end{array}$ & $\begin{array}{c}\text { Memiliki kemampuan } \\
\text { berupa kemampuan } \\
\text { menjawab soal - soal } \\
\text { structure atau grammar }\end{array}$ \\
\hline 3 & Kemampuan dalam & Nilai rendah & $\begin{array}{c}\text { Memiliki kemampuan } \\
\text { berupa kemampuan } \\
\text { menjawab soal - soal } \\
\text { reading comprehension }\end{array}$ \\
\hline 4 & $\begin{array}{c}\text { Pre test dengan nilai yang } \\
\text { sangat rendah }\end{array}$ & $\begin{array}{c}\text { Post test dengan } \\
\text { nilai yang sangat } \\
\text { baik }\end{array}$ & $\begin{array}{c}\text { Adanya peningkatan yang } \\
\text { sangat significant antara } \\
\text { pretest dan posttest }\end{array}$ \\
\hline
\end{tabular}

\section{Kesimpulan}

Berdasarkan proses pelaksanaan dan hasil kegiatan pengabdian kepada masyarakat ini, dapat disimpulkan bahwa:

a. Pelatihan Bahasa Inggris TOEFL merupakan salah satu upaya positif dan nyata yang dapt dilakukan untuk meningkatkan kemampuan penguasaan Bahasa Inggris bagimahasiswa. 
b. Materi pelatihan yang diberikan mencakup strategi - strategi yang sangat berguna untuk menunjang untuk meningkatkan pengetahuan dan kemampuan dalam menjawab tes TOEFL.

Setelah dilaksanakannya kegiatan pengabdian kepada masyarakat berbentuk pelatihan TOEFL ini mahasiswa memiliki kesiapan yang cukup untuk mengikuti tes TOEFL yang menjadi yang sebenarnya.

\section{Ucapan Terima Kasih}

Puji syukur senantiasa tim pengabdi panjatkan ke hadirat Allah SWT yang telah melimpahkan Rahmat serta Petunjuk-Nya, sehingga penyusunan laporan Pengabdian Kepada Masyarakat ini dapat diselesaikan tepat waktu. Pengabdian ini bertema "Training untuk Mencapai Nilai TOEFL Ideal di Masa Pandemi bagi Mahasiswa Universitas Bumigora. Beberapa pihak telah ikut berpartisipasi dalam memberikan sumbangan ide maupun tenaga dalam penyusunan laporan pengabdian ini. Oleh karena itu pada kesempatan ini tim pengabdi ingin menyampaikan penghargaan dan ucapan terima kasih yang sebesarbesarnya kepada:

1. Rektor Universitas Bumigora yang telah memberi kesempatan dan bantuan untuk pelaksanaan Pengabdian Kepada Masyarakat ini.

2. Dekan Fakultas Sastra dan Humaniora dan Dekan Fakultas ekonomi dan bisnis Universitas Bumigora yang telah memberi kesempatan dan dukungan moral untuk pelaksanaan Pengabdian Kepada Masyarakat ini.

3. Ketua LPPM Universitas Bumigora yang telah memberi kesempatan dan bantuan sejak pelaksanaan pengabdian ini.

4. Semua pihak yang tidak dapat tim pengabdi sebutkan satu per satu yang telah banyak membantu terselenggaranya pengabdian kepada masyarakat ini.

Semoga Allah SWT Tuhan semesta alam membalas semuanya dengan sebaik baik balasan. Aaamiiin ya rabbal alamiin. Tim pengabdi menyadari bahwa banyak hal yang disajikan dalam laporan ini masih jauh dari kata sempurna.Oleh karena itu saran dan kritik yang bersifat membangun sangat diharapkan. 


\section{Daftar Pustaka}

Alan, Evision. 1983. Oxford Learner's Pocket Dictionary New York : Oxford University Press.

Artini, L.P. 1998. Is speaking easier than writing?: Exploring the complexity of spoken language. Jurnal IImu Pendidikan, 5, 38-48.

Astin, A.W. 1993. Assesment for excellence: The philosophy and practice of assessment and evaluation in higher education. New York: The OryxPress.

Brown, H. D. 2001. Teaching by Principles: An Interactive Approach to Language pedagogy. N.Y:Longman.

Brown, H.D. 2001. Teaching by principles: An active approach to language pedagogy. (2nded). San Francisco: Addison Wesley Longman, Inc.

Brown, H.D. 2004.Language assessment: Principle and classroom practices. NewYork: Longman, Pearson Education, Inc.

Buck, G. 2001. Assessing listening. Cambridge: Cambridge University Press.

Celce-Murcia, M. 2001. Teaching English as a second or foreign language. (3rded). New York: Heinle and Heinle.

Clapham, C. 1996. The development of IELTS: A study of the effect of background knowledge on reading comprehension. Cambridge: Cambridge University Press.

Crystal, D. 2000. English as a global language. Cambridge: Cambridge University Press.

Horst, Marlise. 2010. First and Second Language Knowledge in the Language Classroom. International Journal of Bilingualism.Vol 14.No. 3. 313-349. Concordia University Montreal

Mazzei, L.A. 2004. Silent Listening: Deconstructive practices in discourse- based research. Journal of American Educational Research Association,33, 26-33.

Philip, Deborah. 2004. Preparation Course for the TOEFL Test. The Paper Test. Longman. Pearson. 